\title{
Shear Bond Strength of Acrylic Teeth to Heat-curing Denture Base Resin under Different Disinfectant Methods
}

\author{
Resistencia al Cizallamiento de Dientes Acrílicos en Bases Protésicas \\ de Resina con Curado Térmico bajo Diferentes Métodos de Desinfección
}

Henis Mian*; Murillo Sucena Pita*; Cássio Do Nascimento*; Flávio Henrique Carriço Nogueira Fernandes*; Paulo Linares Calefi*; Jerônimo Manço de Oliveira-Neto* \& Vinícius Pedrazzi*

MIAN, H.; PITA, M. S.; NASCIMENTO, C.; FERNANDES, F. H. C. N.; CALEFI, P. L.; OLIVEIRA-NETO, J. M. \& PEDRAZZI, V. Shear bond strength of acrylic teeth to heat-curing denture base resin under different disinfectant methods. Int. J. Odontostomat., 7(1):99-105, 2013.

ABSTRACT: The aim of this study was to evaluate the shear bond strength between acrylic teeth and heat-activated acrylic denture base resin using five different disinfectants solutions after simple immersion or under ultrasonic cleaner action. A total of 144 acrylic denture resin specimens were produced with both types of acrylic denture tooth (Biolux $®$ and Trilux ${ }^{\circledR}$ ). The specimens were randomly divided into subgroups according to the disinfection procedure used (immersion in

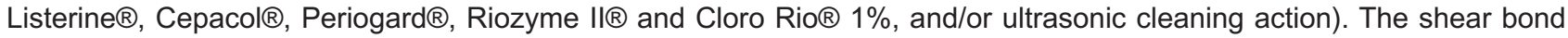
strength between acrylic teeth and denture base was assessed using a universal testing machine and the data obtained were analyzed by means of ANOVA followed by Fisher's LSD Multiple-Comparison test. The two layers teeth presented a bond strength average of $3.43 \mathrm{MPa}$ while the three layer ones had an average of $3.02 \mathrm{MPa}$. The association of ultrasonic cleaner and the disinfectant solutions studied did not affect negatively the teeth bond resistance to the denture base. The three layer acrylic teeth had a lower shear bond strength compared to those with double pressing when immersed in disinfection solutions, regardless of the ultrasonic cleaner use.

KEYWORDS: artificial teeth, disinfectants solutions, heat-polymerized resin, shear bond strength.

\section{INTRODUCTION}

Dental prosthesis has been cited as a source of contamination acting like a reservoir of infection. The prosthesis keeps contact with oral tissues, saliva, microorganisms and many times with blood, when periodontal diseases and oral lesions are detected. In certain steps of prosthetic treatment, dental prosthetic devices can be sent to dental offices for adjustments, repairs or polishing procedures and the materials used for these processes may be contaminated by bacteria, viruses or yeasts from the patient's oral cavity. Then, the risk of cross-infection between patients, dentists and dental laboratories technicians can occur during clinical and laboratory procedures (Davenport, 1972; Kahn et al., 1982; Powell et al., 1990; Brace \& Plummer, 1993).
To prevent cross-infection, all prosthetic and dental appliances should be properly disinfected in the dental office and laboratory before use (Naylor, 1992; Kohn et al., 2003). Thus, chemical disinfection and/or mechanical cleaning acquire a fundamental role in infection-control procedures at the dental and laboratory office, and on the daily routine of dental prostheses users.

The immersion of a denture in a suitable disinfectant solution for an adequate length of time to achieve disinfection is a convenient and inexpensive method. According to Harrison et al. (2004), disinfectant immersion solutions cause fewer injuries to the prosthetic resin than brushing with abrasive dentifrices.

\footnotetext{
Department of Dental Materials and Prosthodontics, Faculty of Dentistry of Ribeirão Preto, University of São Paulo, Ribeirão Preto, São Paulo - Brazil.

"Associate Professor, Department of Dental Materials and Prosthodontics, Faculty of Dentistry of Ribeirão Preto, University of São Paulo, Ribeirão Preto, São Paulo - Brazil.
} 
MIAN, H.; PITA, M. S.; NASCIMENTO, C.; FERNANDES, F. H. C. N.; CALEFI, P. L.; OLIVEIRA-NETO, J. M. \& PEDRAZZI, V. Shear bond strength of acrylic teeth to heat-curing denture base resin under different disinfectant methods. Int. J. Odontostomat., 7(1):99-105, 2013.

However, it had been shown that some disinfectant solutions could produce changes in different physical and mechanical properties of denture base resins, such as decrease in the transverse strength and hardness, degradation of the surface appearance of resins and corrosion of metal surfaces of removable prosthetic devices (Shen et al., 1989; Polyzois et al., 1995; da Silva et al., 2008).

Considering that it is not a method for home use, the ultrasonic device has been used primarily by professionals as an auxiliary method for hygiene of prostheses. Ultrasonic cleaning is more effective than some effervescent denture cleaner products in the reduction of biofilm in prosthetic appliances, and additionally, ultrasonic cleaners could be associated to different disinfectant solutions, enhancing their bactericidal action (Myers \& Krol, 1974; Gwinnett \& Caputo, 1983; Raab et al., 1991). According to Ratnasari et al. (2008), the routine ultrasonic cleaning should be performed to avoid the possible accumulation of microorganisms in the laminated mesh structure of maxillary complete denture. A few studies attempted to evaluate the changes caused on the surface of acrylic prostheses using ultrasonic cleaning (Raab et al.). It was demonstrated that the bond strength between artificial teeth and denture base acrylic resin was somehow affected by the ultrasonic cavitation effect (Kim et al., 2003).

Many factors can contribute to the failure at acrylic tooth and denture base resin interface, as the broad range of denture base resins, artificial teeth and denture processing methods, than produces a wide variability in the reported results of the bonding between acrylic teeth and denture base resin. Some authors have reported that teeth made from conventional acrylic resins achieve a higher bond to denture base resins than cross-linked teeth (Clancy \& Boyer, 1989; Suzuki et al., 1990; Takahashi et al., 2000), and different types of processing methods applied to the base resins and denture teeth can also affect the bond between acrylic teeth and denture base resins (Clancy et al., 1991; Kawara et al., 1991; Vallittu et al., 1997; Chai et al., 2000; Chung et al., 2008).

This inconsistency of results highlights the need for further studies regarding the bond strength between acrylic teeth and denture base materials, and the selection of more compatible combinations of denture base resins and acrylic teeth than might reduce the number of prosthesis fractures and the resultant repairs (Schneider et al., 2002; Patil et al., 2006). The aim of this study was to evaluate the influence of disinfectant solutions, associated or not to ultrasonic cleaning, on the shear bond strength of artificial acrylic teeth to denture base resin.

\section{MATERIAL AND METHOD}

The product name, manufacturers and compositions of the materials used in the present study are listed in Table I.

It was evaluated the shear bond strength of two types of poly (methyl methacrylate) denture based acrylic teeth to a conventional poly (methyl methacrylate) heat-polymerizing acrylic resin (Vip CrilÖ, Dental Vipi Ltda, Pirassununga, Brazil), commonly used for the fabrication of denture bases. A total of 144 artificial teeth were divided into two groups according to themanufacturing process: two layer acrylic teeth (BioluxÒ, n=72) and three layer acrylic teeth (TriluxÒ, $\mathrm{n}=72$ ) which were subdivided in two subgroups according to the disinfection procedures.

Aiming standardization, first molars were selected for the test due to larger contact surface for union with the acrylic base. Five disinfectant solutions and an ultrasonic cleaner were selected and distilled water was used as control. The solutions were employed following the manufacturer's instructions.

Specimen preparation. A PVC tube $(25 \mathrm{~mm} \varnothing$ and 10 $\mathrm{mm}$ high) was filled with dental stone and after hardening it was included in another PVC tube with vinyl polysiloxane impression material (Elite Double 8), creating a matrix to fabricate the standard wax cylinders. The acrylic denture teeth were then fixed upon the cylinders assisted by a parallelometer, allowing central and perpendicular alignment of the teeth on the cylinders surface. Wax templates with the teeth were invested in flasks with dental stone. After the dental stone had set, the flasks were opened and the wax was removed using boiling water. The dental stone was lubricated with a thin layer of acrylic separating film (Cel-LacÒ; SS White Artigos Dentários, Rio de Janeiro, Brazil).

The liquid and powder of the denture base resin were then proportioned and mixed according to manufacturer's instructions and packed at the late dough stage into the cylindrical cavities of the mould and in contact with the teeth. The flasks were clamped, 
MIAN, H.; PITA, M. S.; NASCIMENTO, C.; FERNANDES, F. H. C. N.; CALEFI, P. L.; OLIVEIRA-NETO, J. M. \& PEDRAZZI, V. Shear bond strength of acrylic teeth to heat-curing denture base resin under different disinfectant methods. Int. J. Odontostomat., 7(1):99-105, 2013.

Table I. Products used.

\begin{tabular}{|c|c|c|}
\hline Commercial name & Description & Manufacturer \\
\hline Wilson' & Pink wax n. 7 & Polidental Indústria e Comércio Ltda., Cotia, Brazil. \\
\hline Tubos Tigre’ & PVC tubes & Tigre S/A,Tubos e Conexões, Joinville, SC, Brazil \\
\hline Elite Double $8^{>}$ & addition silicone & Zhermack - Italy \\
\hline Biolux $x^{>}$ & $\begin{array}{l}\text { Dual-layer pressed } \\
\text { polymethylmethacrylate teeth }\end{array}$ & $\begin{array}{l}\text { VIPI Indústria, Comércio, Exportação e Importação de } \\
\text { Produtos Odontológicos Ltda }\end{array}$ \\
\hline Trilux & $\begin{array}{l}\text { Triple-layer pressed } \\
\text { polymethylmethacrylate teeth. }\end{array}$ & $\begin{array}{l}\text { VIPI Indústria, Comércio, Exportação e Importação de } \\
\text { Produtos Odontológicos Ltda }\end{array}$ \\
\hline Vipi Cril & $\begin{array}{l}\text { heat-activated acrylic denture base } \\
\text { resin, bright pink colour }\end{array}$ & $\begin{array}{l}\text { VIPI Indústria, Comércio, Exportação e Importação de } \\
\text { Produtos Odontológicos Ltda }\end{array}$ \\
\hline Listerine $^{\circledR}$ & $\begin{array}{l}\text { Essential oils (thymol, eucalyptol, } \\
\text { menthol and alcohol) }\end{array}$ & Warner-Lambert Co, Morris Plains, Nem Jersey - USA \\
\hline Cepacol & cetylpyridinium chloride & Aventis Pharma Ltda, Suzano - SP, Brazil \\
\hline Periogard ${ }^{\circledR}$ & Chlorhexidine gluconate $0.12 \%$ & $\begin{array}{l}\text { Colgate-Palmolive Indústria e Comércio Ltda, São } \\
\text { Bernardo do Campo - SP, Brazil }\end{array}$ \\
\hline Riozyme $\|{ }^{\circledR}$ & Protease, lipase and amylase & $\begin{array}{l}\text { Indústria Farmacêutica Rioquímica Ltda, São José do } \\
\text { Rio Preto - SP, Brazil }\end{array}$ \\
\hline Cloro Rio $1 \%{ }^{\circledR}$ & Sodium hypochlorite $1 \%$ & $\begin{array}{l}\text { Indústria Farmacêutica Rioquímica Ltda, São José do } \\
\text { Rio Preto - SP, Brasil }\end{array}$ \\
\hline Ultrasonic Cleaner & $\begin{array}{l}1440 \mathrm{D} \text { model, with water heating, } 40 \\
\mathrm{kHz} \text { frequency. }\end{array}$ & Odontobrás, Ribeirão Preto, Brasil. \\
\hline $\begin{array}{l}\text { Universal Testing } \\
\text { Machine EMIC }\end{array}$ & DL 2000 model & $\begin{array}{l}\text { EMIC Equipamentos e Sistemas de Ensaios Ltda. São } \\
\text { José dos Pinhais, Paraná, Brazil, }\end{array}$ \\
\hline
\end{tabular}

pressed using a hydraulic press (Vipi Dental, Pirassununga, São Paulo, SP, Brazil) and submitted a curing cycle of 180 minutes at $60^{\circ} \mathrm{C}$ and 9 hours at $70^{\circ} \mathrm{C}$ in water, after which they were allowed to return to room temperature in the water bath, following conventional procedures required for denture confection and in accordance with the manufacturer's instructions of the base acrylic resin.

After deflasking, trimming and polishing procedures, the obtained specimens were kept immersed in distilled water bath at $37^{\circ} \mathrm{C}$ until the laboratorial trials.

Disinfection methods. To determine the effect of chemical solutions on shear bond strength, specimens $(n=6)$ from each type of acrylic denture teeth were randomly immersed for 60 minutes into a beaker containing one of the five disinfection solutions (Listerine $\AA$, Cepacol $\circledast$, Periogard $₫$, Riozyme $I I \circledast$ and Cloro Rio ${ }^{\circ} 1 \%$ ) or distilled water, in a total of 36 specimens. The other 36 specimens were randomly divided $(n=6)$ and immersed into the five disinfectants solutions or water and placed in an ultrasonic cleaner (4 cycles of 15 minutes), in a total of 60 minutes. The ultrasonic cleaner used produced a potency of $40 \mathrm{kHz}$. All the process was made with two and three layered acrylic denture teeth (Biolux ${ }^{\circledR}$ and Trilux $®$ ).

Shear bond strength testing. After immersion, the resin specimens were removed from the chemical solutions, thoroughly washed in running water, dried with absorbent paper and shear bond strength was evaluated at a Universal Testing Machine (Model DL 2000; EMIC Equipamentos e Sistemas de Ensaio, São José dos Pinhais, PR, Brazil). 
Shear loading was applied on the mesial surface of the tooth using a $0.5 \mathrm{~mm}$ sharp chisel point on acrylic denture teeth / denture base resin interface using a cell load of $50 \mathrm{Kgf}$ at a crosshead speed of $0.5 \mathrm{~mm} /$ min (Fig. 1). The load at fracture was recorded and converted from Kgf to MPa. Shear bond strength was computed using the equation see in Figure 2.

The UTHSCSA Image Tool 2.02 software (Health Science Center, University of Texas, San Antonio) was used to determine the acrylic teeth bonding area.

Statistical analysis. The mean values for all groups was carried out using a three-way analysis of variance (ANOVA) with $5 \%$ significance level, followed by the Fisher's LSD Multiple-Comparison Test. The three factors analyzed were denture tooth, disinfectant solution and ultrasonic cleaner. The statistical software NCSS 2000 (NCSS Statistical Software, Kaysville, USA) was used for all the calculations.

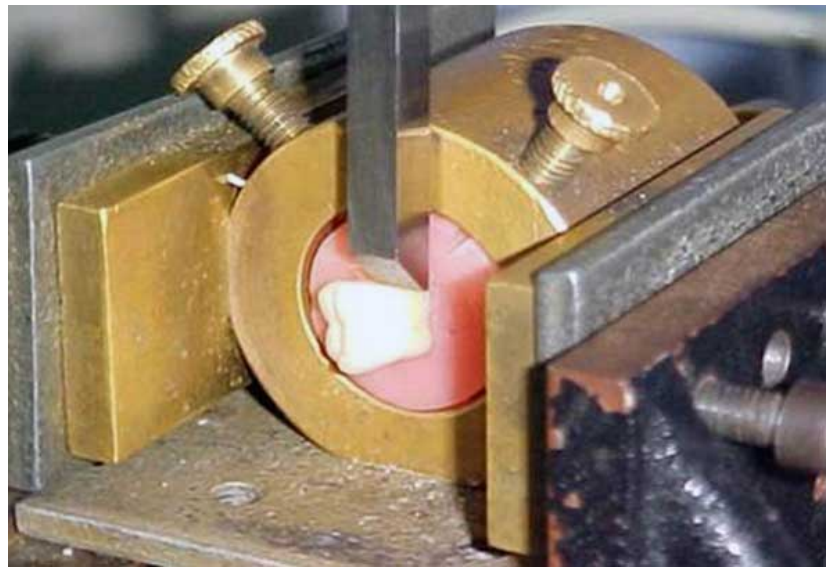

Fig. 1. Shear bond strength testing evaluated at a Universal Testing Machine.

$$
\frac{\mathrm{Fxa}}{\mathrm{A}}=\frac{\mathrm{Kgf \times \textrm {m }} / \mathrm{s}^{2}}{\mathrm{~mm}^{2}}=\mathrm{MPa}
$$

Fig. 2. Equation for shear bond strength determination. $F=$ load at fracture (Kgf), $a=$ crosshead speed $\left(\mathrm{mm} / \mathrm{s}^{2}\right), A=$ acrylic teeth bonding surface area $\left(\mathrm{mm}^{2}\right)$, * Biolux $\AA$ bonding surface area $=65.53$ $\mathrm{mm}^{2},{ }^{*}$ Trilux $®$ bonding surface area $=$ $75.55 \mathrm{~mm}^{2}$.

\section{RESULTS}

The results in Table II indicate that a significant difference was found $(p=0.01)$ between the double and three-layer acrylic denture teeth, Biolux ${ }^{\circledR}$ and Trilux ${ }^{\circledR}$. The immersion of the specimens into different disinfectant solutions $(p=0.14)$, regardless the use or not of ultrasonic cleaner $(p=0.31)$, was not a significant factor.

\section{DISCUSSION}

Different prostheses disinfection procedures have been studied and applied routinely. Brushing and washing with chemical agents, use of effervescent cleansing tablets, microwave irradiation and immersion in disinfectant solutions are commonly used to clean dental prostheses to reduce microorganisms colonization and to avoid the risk of cross-infection (Kahn et al.; Pavarina et al., 2003; Buergers et al., 2008). Several studies have highlighted that some disinfection agents could undermine the properties and structure of denture base resin (Shen et al.; Polyzois et al.; da Silva et al.). Thus, the shear bond strength between denture teeth and base acrylic resin could be directly or indirectly affected.

The results of this study demonstrated that the immersion of the specimens into chemical agents for 60 minutes with or without the ultrasonic effect, did not affect the shear bond strength between acrylic teeth and heat-polymerized acrylic resin evaluated, regardless of the disinfection solution utilized. However, no reports were found in the literature showing the effect of disinfectant solutions on the bond strength between teeth/denture base acrylic resin using exactly this experimental protocol. As a consequence, it was not possible to make a direct comparison with our results.

The absence of any effect of the solutions on the shear bond strength could be attributed to the presence of cross-linking agents on resin materials used in this study. Cross-linking agents are bifunctional monomeric molecules that are added to the polymeric

Table II. Shear bond strength of acrylic teeth into solution and use or not of ultrasonic device (averages in Mpa).

\begin{tabular}{lcccccc}
\hline Condition & Control & Listerine $®$ & Cepacol ${ }^{\circledR}$ & Periogard $\circledast$ & Riozime II® & CloroRio 1\%® \\
\hline & Biolux & Trilux & Biolux & Trilux & Biolux & Trilux \\
Immersed & 4.0 & 3.3 & 3.4 & 2.7 & 3.8 & 2.8 \\
I+US & 3.9 & 3.1 & 3.4 & 2.7 & 3.4 & 3.0 \\
\hline
\end{tabular}


material to allow crossing between linear polymeric chains, forming a network-shaped structure. Ethylene glycol dimethacrylate has been commonly used, improving the resistance to deformation (Price, 1986; Jagger \& Huggett, 1990; Arima et al., 1995). Some researchers studied the effect of cross-linking agents on the water sorption and solubility characteristics of denture base resin (Price; Arima et al., 1996). Jagger \& Huggett mentioned that the addition of cross-linking agents on heat-cured denture base resin provided little effect on water sorption properties, but was an efficient method to improve resistance to solvents. Arima et al. $(1995,1996)$ reported that the cross-linking agent improved the mechanical properties of resin and reduced the denture base's solubility to organic solvents. Based on the results of the present investigation, it may be suggested that the use of a denture resin with cross-linking agents avoided the absorption of the disinfecting solutions, limiting their diffusion in the polymer matrix. This diffusion could result in structural changes and alteration in mechanical properties, such as in the bond strength between acrylic teeth and denture base resin.

The lowest bond strength values were found with Trilux®, a highly cross-linked IPN (interpenetrating polymer network) and triple-pressed acrylic denture tooth, in comparison to the cross-linked IPN doublepressed acrylic denture tooth (Biolux®). This difference could be explained by the structure of these acrylic teeth.

It has been reported that the tooth structure and surface composition of the tooth's ridge lap can affect bonding to the denture base resin (Vallittu et al.; Patil et al.; Chung et al.). Currently, most of the available acrylic teeth are essentially composed by cross-linked polymethyl methacrylate. Cross-linking agents are generally used to improve strength, crazing and staining resistance (Takahashi et al.). The cross-linked polymer matrix is not evenly distributed in the tooth structure and the gingival ridge lap area may not be as highly crosslinked as the incisal area of the tooth. The higher degree of cross linking agents may restrict the diffusion of polymer chains into the denture base to form a polymer network. In contrast, the lowered cross-link density facilitates better chemical bonding between the acrylic tooth and the denture base acrylic resin (Vallittu et al.; Chung et al.). If this latter fact is true, it might in part explain why a lowered cross-link two-layered artificial tooth such as Biolux® had higher bond strength values when compared to Trilux®, a three-layered tooth with a higher degree of cross-linking agents.
The use of ultrasonic bath as an auxiliary method for cleaning dental devices is not recent, and its effectiveness was demonstrated by a decrease in the number of contaminant microorganisms (Myers \& Krol; Gwinnett \& Caputo). Gwinnett \& Caputo, Raab et al., and Ratnasari et al., evaluating the removal of denture surface contaminants after use of ultrasonic cleaning, observed that the cavitation process could modify the physical structure of the denture, decreasing their durability. Kim et al., evaluated the typical stress factors in conventional laboratory procedures for fabricating or repairing dentures. They observed that the ultrasonic cleaning is a typical stress factor during the fabrication or repair of removable partial dentures in laboratory procedures, and resin-to-metal or resin-to-denture tooth bonding may be affected. Those stresses could alter the subsequent impact of energy on the bond junctions by changing the operational temperature range or causing the concentration of ultrasonic energy, which may cause detachment of the bond.

The effects of disinfection procedures and ultrasonic cleaning on adhesion of denture teeth and denture base acrylic resin are not available in the literature. The limited number of investigations on this issue, the lack of uniformity in the testing methods and the variety of products tested make recommendations for laboratory practice difficult to be formulated. Results from this study suggest that the shear bond strength of denture teeth bonded to denture base resin can be considerably altered by the composition of denture tooth. The interpretation of such results should be made with caution. The absence of differences on the bond strength could probably be related to the number of factors analyzed together (type of artificial teeth, disinfecting solutions and association of ultrasound cleaning). Other investigations must be conducted with these factors separated to check the real importance of each one of them on shear bond strength between acrylic resin and denture teeth.

\section{CONCLUSION}

The disinfectant solutions tested did not produce significant alteration on shear bond strength between acrylic denture teeth and denture base resin. There was no significant effect in the shear bond strength when the ultrasonic cleaner was associated to the solutions. Double pressed acrylic teeth presented higher shear bond strength than triple pressed teeth in the tested conditions. 


\section{ACKNOWLEDGEMENTS}

We are grateful to Dental Vipi Ltda. and Odontobrás for supporting this study donating some of the tested materials.

MIAN, H.; PITA, M. S.; NASCIMENTO, C.; FERNANDES, F. H. C. N.; CALEFI, P. L.; OLIVEIRA-NETO, J. M. \& PEDRAZZI, V. Resistencia al cizallamiento de dientes acrílicos en bases protésicas de resina con curado térmico bajo diferentes métodos de desinfección. Int. J. Odontostomat., 7(1):99-105, 2013.

RESUMEN: El objetivo de este estudio fue evaluar la resistencia al cizallamiento entre dientes de resina acrílica y bases acrílicas curadas mediante calor, junto al uso de cinco soluciones de desinfectantes diferentes, mediante inmersión simple o bajo ultrasonido. Un total de 144 bases de acrílico fueron confeccionadas con los dos tipos de dientes de resina (Biolux $®$ y Trilux $®$ ). Los especímenes se dividieron aleatoriamente en subgrupos de acuerdo con el procedimiento de desinfección utilizado (inmersión en Listerine $\AA$, Cepacol $\AA$, Periogard $₫$, Riozyme II ${ }^{\circledR}$ y Cloro Río ${ }^{\circledR} 1 \%$, y/o acción de limpieza por ultrasonido). Se evaluó la resistencia al cizallamiento entre los dientes de resina y la base de la prótesis utilizando una máquina de ensayo universal; los datos obtenidos se analizaron mediante ANOVA seguido por el test LSD de Fisher de comparaciones múltiples. Las dos capas de los dientes presentaron una fuerza de adherencia promedio de $3,43 \mathrm{MPa}$, mientras que las tres capas tenían un promedio de 3,02 MPa. La asociación de limpiador ultrasónico y las soluciones desinfectantes estudiados no afectaron negativamente la resistencia de los dientes a la base de la prótesis. Las tres capas de acrílico de los dientes tuvieron una resistencia al cizallamiento menor en comparación con aquellos con doble prensado cuando se sumergen en soluciones desinfectantes, independientemente del uso de limpiador ultrasónico.

PALABRAS CLAVE: dientes artificiales, soluciones desinfectantes, resina polimerizada al calor, resistencia al cizallamiento.

\section{REFERENCES}

Arima, T.; Hamada, T. \& McCabe, J. F. The effects of crosslinking agents on some properties of HEMA-based resins. J. Dent. Res., 74(9):1597-601, 1995.

Arima, T.; Murata, H. \& Hamada, T. The effects of crosslinking agents on the water sorption and solubility characteristics of denture base resin. J. Oral Rehabil., 23(7):476-80, 1996.
Brace, M. L. \& Plummer, K. D. Practical denture disinfection. J. Prosthet. Dent., 70(6):538-40, 1993.

Buergers, R.; Rosentritt, M.; Schneider-Brachert, W.; Behr, M.; Handel, G. \& Hahnel, S. Efficacy of denture disinfection methods in controlling Candida albicans colonization in vitro. Acta Odontol. Scand., 66(3):17480, 2008.

Chai J.; Takahashi, Y.; Takahashi, T. \& Habu, T. Bonding durability of conventional resinous denture teeth and highly crosslinked denture teeth to a pour-type denture base resin. Int. J. Prosthodont., 13(2):112-6, 2000.

Chung, K. H.; Chung, C. Y. \& Chan, D. C. Effect of preprocessing surface treatments of acrylic teeth on bonding to the denture base. J. Oral Rehabil., 35(4):268-75, 2008.

Clancy, J. M. \& Boyer, D. B. Comparative bond strengths of light-cured, heat-cured, and autopolymerizing denture resins to denture teeth. J. Prosthet. Dent., 61(4):457-62, 1989.

Clancy, J. M.; Hawkins, L. F.; Keller, J. C. \& Boyer, D. B. Bond strength and failure analysis of light-cured denture resins bonded to denture teeth. J. Prosthet. Dent., 65(2):315-24, 1991

da Silva, F. C.; Kimpara, E. T.; Mancini, M. N.; Balducci, I.; Jorge, A. O. \& Koga-Ito, C. Y. Effectiveness of six different disinfectants on removing five microbial species and effects on the topographic characteristics of acrylic resin. J. Prosthodont., 17(8):627-33, 2008.

Davenport, J. C. The denture surface. Br. Dent. J., 133(3):101-5, 1972.

Gwinnett, A. J. \& Caputo, L. The effectiveness of ultrasonic denture cleaning: a scanning electron microscope study. J. Prosthet. Dent., 50(1):20-5, 1983.

Harrison, Z.; Johnson, A. \& Douglas, C. W. An in vitro study into the effect of a limited range of denture cleaners on surface roughness and removal of Candida albicans from conventional heat-cured acrylic resin denture base material. J. Oral Rehabil., 31(5):460-7, 2004.

Jagger, R. G. \& Huggett, R. Effect of cross-linking on sorption properties of a denture-base material. Dent. Mater., 6(4):276-8, 1990.

Kahn, R. C.; Lancaster, M. V. \& Kate, W. Jr. The microbiologic cross-contamination of dental prostheses. J. Prosthet. Dent., 47(5):556-9, 1982.

Kawara, M.; Carter, J. M.; Ogle, R. E. \& Johnson, R. R. Bonding of plastic teeth to denture base resins. J. Prosthet. Dent., 66(4):566-71, 1991. 
MIAN, H.; PITA, M. S.; NASCIMENTO, C.; FERNANDES, F. H. C. N.; CALEFI, P. L.; OLIVEIRA-NETO, J. M. \& PEDRAZZI, V. Shear bond strength of acrylic teeth to heat-curing denture base resin under different disinfectant methods. Int. J. Odontostomat., 7(1):99-105, 2013.

Kim, J. Y.; Pfeiffer, P. \& Niedermeier, W. Effect of laboratory procedures and thermocycling on the shear bond strength of resin-metal bonding systems. J. Prosthet. Dent., 90(2):184-9, 2003.

Kohn, W. G.; Collins, A. S.; Cleveland, J. L.; Harte, J. A.; Eklund, K. J. \& Malvitz, D. M. Guidelines for infection control in dental health-care settings--2003. MMWR. Recomm. Rep., 52(RR-17):1-61, 2003.

Myers, H. M. \& Krol, A. J. Effectiveness of a sonic-action denture cleaning program. J. Prosthet. Dent., 32(6):6138, 1974.

Naylor, W. P. Infection control in fixed prosthodontics. Dent. Clin. North Am., 36(3):809-31, 1992.

Patil, S. B.; Naveen, B. H. \& Patil, N. P. Bonding acrylic teeth to acrylic resin denture bases: a review. Gerodontology, 23(3):131-9, 2006.

Pavarina, A. C.; Pizzolitto, A. C.; Machado, A. L.; Vergani, C. E. \& Giampaolo, E. T. An infection control protocol: effectiveness of immersion solutions to reduce the microbial growth on dental prostheses. J. Oral Rehabil., 30(5):532-6, 2003.

Polyzois, G. L.; Zissis, A. J. \& Yannikakis, S. A. The effect of glutaraldehyde and microwave disinfection on some properties of acrylic denture resin. Int. J. Prosthodont., 8(2):150-4, 1995.

Powell, G. L.; Runnells, R. D.; Saxon, B. A. \& Whisenant, B. $K$. The presence and identification of organisms transmitted to dental laboratories. J. Prosthet. Dent., 64(2):235-7, 1990.

Price, C. A. The effect of cross-linking agents on the impact resistance of a linear poly(methyl methacrylate) denturebase polymer. J. Dent. Res., 65(7):987-92, 1986.

Raab, F. J.; Taylor, C. A.; Bucher, J. A. \& Mann, B. L. Scanning electron microscopic examination of ultrasonic and effervescent methods of surface contaminant removal from complete dentures. J. Prosthet. Dent., 65(2):255-8, 1991.

Ratnasari, A.; Hasegawa, K.; Yoshihara, K.; Nagaoka, N.; Kokeguchi, S.; Nishigawa, G.; et al. Deformation of mesh type stainless palatal plate of maxillary complete denture and the growth of microorganisms. Nihon Hotetsu Shika Gakkai Zasshi, 52(4):555-8, 2008.

Schneider, R. L.; Curtis, E. R. \& Clancy, J. M. Tensile bond strength of acrylic resin denture teeth to a microwave- or heat-processed denture base. J. Prosthet. Dent., 88(2):145-50, 2002.
Shen, C.; Javid, N. S. \& Colaizzi, F. A. The effect of glutaraldehyde base disinfectants on denture base resins. J. Prosthet. Dent., 61(5):583-9, 1989.

Suzuki, S.; Sakoh, M. \& Shiba, A. Adhesive bonding of denture base resins to plastic denture teeth. J. Biomed. Mater. Res., 24(8):1091-103, 1990.

Takahashi, Y.; Chai, J.; Takahashi, T. \& Habu, T. Bond strength of denture teeth to denture base resins. Int. J. Prosthodont., 13(1):59-65, 2000.

Vallittu, P. K.; Ruyter, I. E. \& Nat, R. The swelling phenomenon of acrylic resin polymer teeth at the interface with denture base polymers. J. Prosthet. Dent., 78(2):194-9, 1997.

Correspondence to:

Prof. Dr. Vinícius Pedrazzi

Faculty of Dentistry of Ribeirão Preto

Department of Dental Materials and Prosthodontics

University of São Paulo

Av. Café S/N, Ribeirão Preto, SP

CEP: $14040-904$

BRAZIL

Phone: +55-16-3602-4008

Fax: +55-16-3602-0547

Email: pedrazzi@forp.usp.br

Received: 18-07-2012

Accepted: 26-09-2012 